\title{
Morphological and Molecular Diversity of a Collection of Cucurbita maxima Landraces
}

\author{
María Ferriol, Belén Picó, and Fernando Nuez \\ Center for Conservation and Breeding of the Agricultural Diversity (COMAV), Polytechnic University \\ of Valencia, Camino de Vera 14, Valencia 46022, Spain
}

AdDITIONAL INDEX WORDs. germplasm collection, squash, SRAP markers, AFLP markers, morphological type

\begin{abstract}
Cucurbita maxima Duch. is one of the most morphologically variablecultivated species. The Centerfor Conservation and Breeding of the Agricultural Diversity (COMAV) holds a diverse germplasm collection of the Cucurbita genus, with more than 300 landraces of this species. Morphological and molecular characterization are needed to facilitate farmer and breeder use of this collection. With this aim, the morphological variation of a collection of 120 C. maxima accessions was evaluated. The majority of these accessions originated from Spain, which has acted as a bridge since the $16^{\text {th }}$ century for spreading squash morphotypes between the Americas and Europe. South American landraces (the center of origin of this species) were also included. Eight morphological types were established based on this characterization and previous intraspecific classifications. A subset of these accessions, selected from these classification and passport data, was employed for molecular characterization. Two marker types were used; sequence related amplified polymorphism (SRAP), which preferentially amplifies open reading frames (ORF), and amplified fragment length polymorphism (AFLP). In the main, SRAP marker analysis grouped accessions in accordance to their type of use (agronomic traits) and AFLP marker analysis grouped accessions as to their geographical origin. AFLP marker analysis detected a greater genetic variability among American than among Spanish accessions. This is likely due to a genetic bottleneck that may have occurred during the introduction of squash into Europe. The disparity of the results obtained with the two markers may be related to the different genome coverage which is characteristic of each particular marker type and/or to its efficiency in sampling variation in a population.
\end{abstract}

Cucurbita maxima Duch. is an extremely diverse species. It has been suggested that it has more cultivated forms than any other crop (Esquinas-Alcázar and Gulick, 1983). This species originated in South America from wild, free-living C. maxima ssp. andreana (Naud.) Filov over 4000 years ago, and apparently did not migrate from its continental origin during the pre-Columbian era (Sanjur et al., 2002). Different squash types of this species were introduced into Western Europe as early as the $16^{\text {th }}$ century, when they were depicted and described in diverse botanical works (Paris, 2001). Spain acted as a bridge between South America and Europe for the dispersion of squash ecotypes, which spread rapidly towards other continents (Decker-Walters and Walters, 2000). India, Bangladesh and Myanmar are considered to be secondary centers of diversity for C. maxima (Esquinas-Alcázar and Gulick, 1983).

Cucurbita maxima is a basic element in traditional subsistence agriculture in South America, where an enormous diversity of landraces exists (Lira-Saade, 1995). In Spain, a similar situation to that of South America is currently occurring. Major production incorporates the use of landraces, mainly for self-consumption and sale in local markets. The potential of this germplasm for use in breeding has encouraged the Center for Conservation and Breeding of Agricultural Diversity (COMAV) at the Polytechnic University of Valencia to increase its collection of C. maxima to over 300 accessions since the 1980s. This collection includes accessions from all the regions of Spain and some South American countries. The accessions are used at their points of origin for human consumption, as fodder for livestock and/or as ornamental varieties. The activities of the COMAV concerning genetic resources of Cucurbitaceae are conducted within the European Cooperative Programme for Crop Genetic Resources Network (ECP/GR), which was developed by the International

Received for pulication 15 Jan. 2003. Accepted for publication 23 July 2003.
Plant Genetic Resources Institute (IPGRI). Currently, the COMAV houses the European database of this family.

To increase this collection's utility for breeders and farmers, morphological and molecular characterization of this germplasm is needed. Recent morphological classifications of C. maxima are mainly modifications of that proposed by Castetter (1925). However, not all of the landraces of this species can be placed into this varietal grouping (Robinson and Decker-Walters, 1997). Most molecular analyses performed to date on C. maxima have focused on the establishment of phylogenetic relationships among Cucurbita species (Decker-Walters et al., 1990; Ganal and Hemleben, 1986; Goldberg et al., 1972; Jobst et al., 1998; Katzir et al., 1996; King et al., 1995; Sanjur et al., 2002; Weeden and Robinson, 1990; Wilson et al., 1992). Only a few studies have focused on morphological and/or molecular diversity analysis within this species (Joshi et al., 1993; Júnior, 1999). Recently, the genetic diversity among 19 Spanish accessions of C. maxima was studied using two different molecular marker types: sequence related amplified polymorphism (SRAP) (Li and Quiros, 2001), which preferentially amplify open reading frames (ORFs), and random amplified polymorphic DNA (RAPD) (Ferriol etal., 2003a). The usefulness of the SRAP technique for detecting polymorphism in ORFs was proved in this study by sequencing some DNA fragments. Whereas RAPD markers did not group accessions in relation to fruit type (agronomic traits) or passport data (origin and agroclimate conditions), SRAP markers grouped the accessions examined according to their type of use (i.e., human consumption, animal fodder and/or ornamental varieties), which has breeding value. These results indicated that SRAP markers were suitable for the characterization of germplasm collections. Other molecular markers [amplified fragment length polymorphism (AFLP), inter-simple sequence repeat (ISSR) and simple sequence repeat (SSR)] have also been used for analyzing the genetic diversity in other Cucurbita species, such as C. pepo (Ferriol et al., 2003b; Katzir et al., 2000; Paris et al., 2003). 
In the present work, a study was designed to analyze the genetic diversity of the collection of $C$. maxima landraces from Spain and South America held at COMAV. Two marker types were used: SRAP and AFLP. The knowledge of the diversity of this germplasm will facilitate its use in breeding programs and improve the management of large collections of this species.

\section{Materials and Methods}

Plant material. The $302 C$. maxima accessions held at the COMAV were grouped on the basis of their passport data, fundamentally geographical origin, local name, type of use and descriptions reported by the farmers. This grouping allowed a tentative identification of possible duplicate accessions, and led to the selection of a representative subset having broad morphological variability and diverse geographical origin. Therefore, 120 accessions were used for morphological characterization: 109 Spanish accessions (Fig. 1), nine South American accessions (Peru, Bolivia, Ecuador and Argentina), one Moroccan accession and one New Zealand accession. All the accessions were landraces, also the South American, which were collected in Indian local markets.

Table 1. Descriptive data of the Cucurbita maxima accessions used for SRAP and AFLP analysis, grouped according to morphological groups

\begin{tabular}{|c|c|c|c|c|c|c|}
\hline \multirow{2}{*}{\multicolumn{2}{|c|}{ Morphological group }} & \multirow{3}{*}{$\begin{array}{l}\text { Accession } \\
\text { AN117 } \\
\text { CA138 } \\
\end{array}$} & \multicolumn{2}{|c|}{ Origin } & \multirow[b]{2}{*}{ Local Use } & \multirow[b]{2}{*}{$\begin{array}{c}\text { Cultivar name or local } \\
\text { name }\end{array}$} \\
\hline & & & Province or state & Country & & \\
\hline Turban $(T)$ & & & $\begin{array}{l}\text { Andalucía } \\
\text { Canarias }\end{array}$ & $\begin{array}{l}\text { Spain } \\
\text { Spain }\end{array}$ & $\begin{array}{l}\text { Ornamental } \\
\text { Ornamental }\end{array}$ & $\begin{array}{l}\text { Calabaza adorno } \\
\text { Calabaza adorno }\end{array}$ \\
\hline Banana (B) & & $\mathrm{CL}^{2}$ & Castilla and León & Spain & - & - \\
\hline \multirow{3}{*}{$\begin{array}{l}\text { Flattened } \\
\text { with orange } \\
\text { flesh (FO) }\end{array}$} & White & $\mathrm{B} 22^{2}$ & Baleares & Spain & Human & Calabaza de cocinar \\
\hline & $\begin{array}{l}\text { Grey } \\
\text { and } \\
\text { smooth }\end{array}$ & 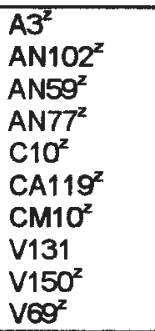 & $\begin{array}{l}\text { Aragón } \\
\text { Andalucia } \\
\text { Andalucia } \\
\text { Andalucia } \\
\text { Cataluña } \\
\text { Canarias } \\
\text { Castilla-la-Mancha } \\
\text { Valencia } \\
\text { Valencia } \\
\text { Valencia }\end{array}$ & $\begin{array}{l}\text { Spain } \\
\text { Spain } \\
\text { Spain } \\
\text { Spain } \\
\text { Spain } \\
\text { Spain } \\
\text { Spain } \\
\text { Spain } \\
\text { Spain } \\
\text { Spain }\end{array}$ & $\begin{array}{l}\text { Human } \\
\text { Human } \\
\text { Human } \\
\text { Human } \\
\text { Human } \\
\text { Human } \\
\text { Human } \\
\text { Human } \\
\text { Human } \\
\text { Human }\end{array}$ & $\begin{array}{l}\text { Calabaza asar } \\
\text { - } \\
\text { Calabaza verrugosa } \\
\text { Calabaza de Benaharas } \\
\text { - } \\
\text { Calabaza } \\
\text { Calabaza de asar } \\
\text { Calabaza } \\
\text { - } \\
\text { Calabaza de asar }\end{array}$ \\
\hline & $\begin{array}{l}\text { Dark } \\
\text { and } \\
\text { warted }\end{array}$ & $\begin{array}{l}\text { AN100 } \\
\text { AN20 } \\
\text { CM133 } \\
\text { MU5 } \\
\text { V1 } \\
\text { V148 } \\
\text { V194 }\end{array}$ & $\begin{array}{l}\text { Andalucia } \\
\text { Andalucía } \\
\text { Castilla-la-Mancha } \\
\text { Murcia } \\
\text { Valencia } \\
\text { Valencia } \\
\text { Valencia }\end{array}$ & $\begin{array}{l}\text { Spain } \\
\text { Spain } \\
\text { Spain } \\
\text { Spain } \\
\text { Spain } \\
\text { Spain } \\
\text { Spain }\end{array}$ & $\begin{array}{l}\text { Human } \\
\text { Human } \\
\text { Human } \\
\text { Human } \\
\text { Human } \\
\text { Human } \\
\text { Human }\end{array}$ & $\begin{array}{l}\text { Calabaza roteña } \\
\text { Calabaza de asar } \\
\text { Calabaza Totana } \\
\text { - } \\
\text { Calabaza verde } \\
\text { - }\end{array}$ \\
\hline \multicolumn{2}{|c|}{$\begin{array}{l}\text { Flattened to globular } \\
\text { with light flesh (FGL) }\end{array}$} & $\begin{array}{l}\text { ECU143 } \\
\text { BOL1 } \\
\text { C41 } \\
\text { CL1 } \\
\text { CL2 } \\
\text { CL6 } \\
\text { CL7 } \\
\text { CM3 } \\
\text { E1 } \\
\text { E15 } \\
\text { PV2 }\end{array}$ & $\begin{array}{l}\text { La Paz } \\
\text { Cataluña } \\
\text { Castilla and León } \\
\text { Castilla and León } \\
\text { Castilla and León } \\
\text { Castilla and León } \\
\text { Castilla-la-Mancha } \\
\text { Extremadura } \\
\text { Extremadura } \\
\text { País Vasco }\end{array}$ & $\begin{array}{l}\text { Ecuador } \\
\text { Bolivia } \\
\text { Spain } \\
\text { Spain } \\
\text { Spain } \\
\text { Spain } \\
\text { Spain } \\
\text { Spain } \\
\text { Spain } \\
\text { Spain } \\
\text { Spain }\end{array}$ & $\begin{array}{l}\text { Cattle } \\
\text { - } \\
\text { Cattle } \\
\text { Cattle } \\
\text { Cattle } \\
\text { Cattle } \\
\text { Cattle } \\
\text { Cattle } \\
\text { Cattle } \\
\text { Cattle } \\
\text { Cattle }\end{array}$ & $\begin{array}{l}\text { Zapallo } \\
\text { Calabaza } \\
\text { Calabaza } \\
\text { Calabaza roja } \\
\text { Calabaza } \\
\text { Calabaza } \\
\text { Calabaza } \\
\text { Calabaza } \\
\text { Calabaza grande } \\
\text { Calabaza } \\
\text { Calabaza amarilla }\end{array}$ \\
\hline \multirow{2}{*}{$\begin{array}{l}\text { Globular } \\
\text { with orange } \\
\text { flesh (GO) }\end{array}$} & Orange & V196 & Valencia & Spain & - & - \\
\hline & Grey & $\begin{array}{l}\mathrm{C} 4^{2} \\
\mathrm{~V} 121^{2}\end{array}$ & $\begin{array}{l}\text { Cataluña } \\
\text { Valencia }\end{array}$ & $\begin{array}{l}\text { Spain } \\
\text { Spain }\end{array}$ & $\begin{array}{l}\text { Human } \\
\text { Human }\end{array}$ & $\begin{array}{l}\text { Calabaza de asar } \\
\text { Calabaza de asar }\end{array}$ \\
\hline $\begin{array}{l}\text { Cylindrical } \\
\text { to oval }(\mathrm{CO})\end{array}$ & & $\begin{array}{l}\text { ECU1712 } \\
\text { BOL2 } 2^{2} \\
\text { AN5 } \\
\text { AS1 }{ }^{2} \\
\text { V138 }\end{array}$ & $\begin{array}{l}\text { Azuay } \\
\text { Tarija } \\
\text { Andalucia } \\
\text { Asturias } \\
\text { Valencia }\end{array}$ & $\begin{array}{l}\text { Ecuador } \\
\text { Bolivia } \\
\text { Spain } \\
\text { Spain } \\
\text { Spain }\end{array}$ & $\begin{array}{l}- \\
\text { Human } \\
\text { Cattle } \\
\text { Human }\end{array}$ & $\begin{array}{l}\text { Zapallo } \\
\text { Calabaza } \\
\text { Calabaza blanca } \\
\text { Calabazón } \\
\text { Calabaza asar }\end{array}$ \\
\hline \multicolumn{2}{|c|}{ Heart-shaped (HS) } & $\begin{array}{l}\text { PER620 } \\
\text { AN107 }\end{array}$ & $\begin{array}{l}\text { Piura } \\
\text { Andalucía }\end{array}$ & $\begin{array}{l}\text { Peru } \\
\text { Spain }\end{array}$ & - & $\begin{array}{l}\text { Zapallo } \\
\text { Calabaza Totana }\end{array}$ \\
\hline \multicolumn{2}{|c|}{ Similar to Hubbard (SH) } & ECU258 & Pichincha & Ecuador & - & Zapallo \\
\hline \multicolumn{2}{|c|}{ Unclassified (U) } & $\begin{array}{l}\text { PER677 } \\
\text { PER459 } \\
\text { ARG6 } \\
\text { AFR19² } \\
\text { OCE1 } \\
\text { AN71 } \\
\text { CM34 }\end{array}$ & $\begin{array}{l}\text { Cuzco } \\
\text { Lima } \\
\text { Afourer } \\
- \\
\text { - } \\
\text { Andalucia } \\
\text { Castilla-la-Mancha }\end{array}$ & $\begin{array}{l}\text { Peru } \\
\text { Peru } \\
\text { Argentina } \\
\text { Morocco } \\
\text { New Zealand } \\
\text { Spain } \\
\text { Spain }\end{array}$ & $\begin{array}{l}\text { - } \\
- \\
\text { - } \\
\text { Ornamental } \\
- \\
\text { Human }\end{array}$ & $\begin{array}{l}\text { Zapallo } \\
- \\
- \\
\text { Calabaza ornamental } \\
\text { Calabaza gorda } \\
\text { - } \\
\text { Calabaza de asar }\end{array}$ \\
\hline
\end{tabular}

${ }^{2}$ Accessions selected for AFLP analysis based on SRAP results and morphological classification. 


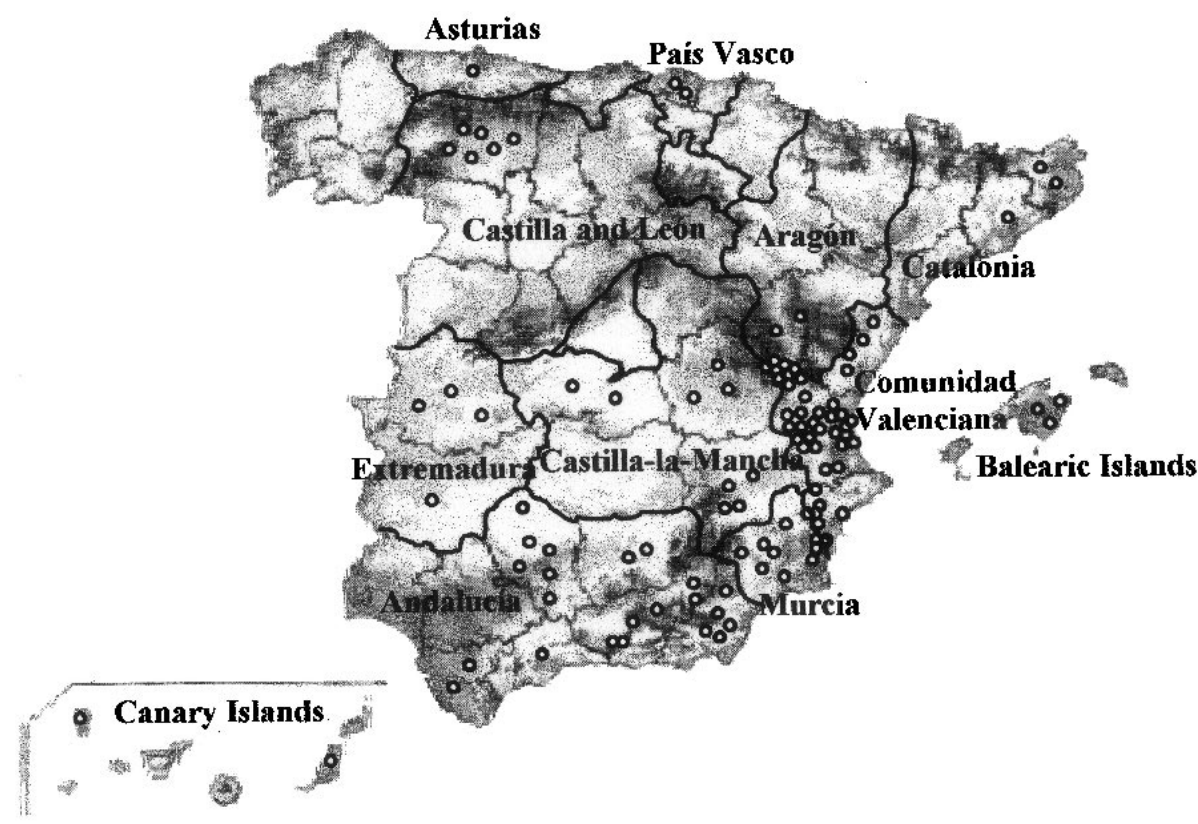

Fig. 1. Origin of the 109 Spanish accessions of Cucurbita maxima used in the morphological characterization.

For molecular characterization using SRAP, 50 accessions of C. maxima of the 120 previous subset were used (Table 1). This sample was representative of the morphological variability and passport data. For AFLP analysis, 38 accessions out of the 50 analyzed with SRAP were selected in accordance with the SRAP grouping and morphological types.

MORPHOLOGICAL CHARACTERIZATION. In May 2001, seeds from the 120 acessions were germinated in the greenhouse. Ten plants per accession were transplanted $15 \mathrm{~d}$ later in an open field of the Polytechnic University of Valencia (Spain), with a plant spacing of $3 \times 3 \mathrm{~m}$. The arable soil of this region displays a sandy texture and a high organic matter content. The standard agronomic practices for this location were followed.

For the morphological characterization, the standard descriptor set for Cucurbitaceae advocated by the IPGRI (Esquinas-Alcázar and Gulick, 1983) was used. The growth habit, visually recorded as prostrate, bushy or intermediate, was evaluated between the first and second month after transplanting. The following traits were recorded or calculated for each fruit (considering all the fruit of an accession) at physiological maturity: shape, ribbing and color of the fruit; texture and hardness of the skin; flesh and seed color; weight $(\mathrm{kg})$, length and width of the fruit ( $\mathrm{mm})$ (measured with a ruler); length:width ratio (fruit shape); skin and flesh thickness (mm); length, width, thickness ( $\mathrm{mm}$ ) (measured with a caliper) and weight (mg) of the seeds; and flesh thickness squared:length per

Table 2. Primer sequences used for SRAP and AFLP analysis.

\begin{tabular}{llll}
\hline SRAP primer & Sequence (5'-3') & AFLP Primer & Sequence (5'-3') \\
\hline ME-2 (forward) & TGAGTCCAAACCGGAGC & EcoRI-ACA & GAC TGC GTA CCAATT CAC A \\
ME-6 (forward) & TGAGTCCTTTCCGGTAA & EcoRI-AAC & GAC TGC GTA CCA ATT CAA C \\
ME-7 (forward) & TGAGTCCTTTCCGGTCC & EcoRI-AGG & GAC TGC GTA CCA ATT CAG G \\
ME-8 (forward) & TGAGTCCTTTCCGGTGC & Mse-CT & GAT GAG TCC TGA GTA ACT \\
EM-1 (reverse) & GACTGCGTACGAATTCAAT & Mse-CA & GAT GAG TCC TGA GTA ACA \\
EM-2 (reverse) & GACTGCGTACGAATTCTGC & Mse-CG & GAT GAG TCC TGA GTA ACG \\
EM-3 (reverse) & GACTGCGTACGAATTCGAC & Mse-CC & GAT GAG TCC TGA GTA ACC \\
EM-5 (reverse) & GACTGCGTACGAATTCAAC & & \\
EM-6 (reverse) & GACTGCGTACGAATTCCAA & & \\
\hline
\end{tabular}

width ratio (an estimate of the proportion of flesh in the fruit). The qualitative traits were scored visually using the codes presented in the descriptor list.

DNAEXTRACTION. GenomicDNAwas isolated from leaves using the modified CTAB method of Doyle and Doyle (1990). For each accession, $0.5 \mathrm{~g}$ of ground leaf tissue from a bulk of 10 plants was suspended in $2.5 \mathrm{~mL}$ of extraction buffer (20 mm EDTA, 0.1 M Tris$\mathrm{HCl}(\mathrm{pH} 8), 1.4 \mathrm{M} \mathrm{NaCl}, 2 \%$ CTAB and $5 \mu \mathrm{L}$ of $\beta$-mercaptoethanol). The suspension was mixed well, incubated at $60{ }^{\circ} \mathrm{C}$ for $30 \mathrm{~min}$, followed by 24 chloroform: 1 isoamylalcohol extraction, and precipitation with two-thirds of the volume of isopropanol at $-20^{\circ} \mathrm{C}$. The pellet formed after centrifugation for $5 \mathrm{~min}$ was washed with $1 \mathrm{~mL}$ of $76 \%$ ethanol and $10 \mathrm{~mm}$ of ammonium acetate. The DNA was then suspended in TE buffer. The resultant DNA concentration was measured in a $1 \%$ agarose gel stained with ethidium bromide using 1-D Manager (2.0), compared with the known concentration of Arabidopsis thaliana DNA (AFLP Core Reagent Kit of Invitrogen, Barcelona, Spain).

SRAP ANALYSIS. Fifty $C$. maxima accessions were analyzed with nine SRAP primers. The SRAP technique consists of preferential amplification of ORFs using PCR (Li and Quiros, 2001). For this purpose, combinations of two types of primers are employed. The first type of primer (forward) amplifies preferentially exonic regions. The second type of primer (reverse) amplifies preferentially intronic regions and regions with promoters. Ten different primer combinations were employed using four forward and five reverse primers selected from previous studies (Ferriol et al., 2003a) (Table 2). Each $25 \mu \mathrm{L}$ PCR reaction mixture consisted of $20 \mathrm{ng}$ genomic DNA, $200 \mu \mathrm{m}$ dNTPs, $1.5 \mathrm{~mm} \mathrm{MgCl}_{2}, 0.3 \mu \mathrm{m}$ primer, $10 \times$ Taq buffer and 1 unit of Taq polymerase (Roche, Mannheim, Germany). Samples were subjected to the following thermal profile: 5 min of denaturing at $94^{\circ} \mathrm{C}$, five cycles of three steps: 1 min of denaturing at $94{ }^{\circ} \mathrm{C}, 1 \mathrm{~min}$ of annealing at $35^{\circ} \mathrm{C}$ and $2 \mathrm{~min}$ of elongation at $72{ }^{\circ} \mathrm{C}$. In the following 30 cycles the annealing temperature was increased to $50{ }^{\circ} \mathrm{C}$, with a final elongation step of $5 \mathrm{~min}$ at $72{ }^{\circ} \mathrm{C}$. Separation of amplification fragments was accomplished on $12 \%$ polyacrylamide gels [acrylamide-bisacrylamide (29:1), TBE 1×] at $500 \mathrm{~V}$ during $11 \mathrm{~h}$. The gels were dried overnight, and subsequently SRAP fragments between 110 and 950 bp were scored as present (1) or absent (0).

AFLP ANALYSIS. Based on the SRAPresults and morphological diversity, 38 accessions were selected for the AFLP analysis (Table 1). 
The AFLPanalysis followed the protocol described previously Foster City). Raw data was analyzed with GeneScan 3.1.2 analysis (Ferriol etal., 2003b). Electrophoresis was conducted using an ABI software (Perkin Elmer Applied Biosystems) and the resulting PRISM 310 Genetic Analyzer(Perkin Elmer Applied Biosystems, GeneScan trace files were imported into Genographer (Benham,

Table 3. Morphological characteristics of the eight morphotypes and unclassified accessions of Cucurbita maxima.

\begin{tabular}{|c|c|c|c|c|c|c|c|c|}
\hline $\begin{array}{l}\text { Morphological } \\
\text { group }\end{array}$ & $\begin{array}{l}\text { Fruit } \\
\text { shape }\end{array}$ & $\begin{array}{l}\text { Growth } \\
\text { habit }\end{array}$ & Fruit ribs & $\begin{array}{l}\text { Fruit } \\
\text { color }\end{array}$ & Skin texture & $\begin{array}{c}\text { Skin } \\
\text { hardness }\end{array}$ & Flesh color & Seed color \\
\hline Turban & $\begin{array}{l}\text { Turbaniform } \\
\text { superior }\end{array}$ & Prostrate & Absent & Red, white & $\begin{array}{l}\text { Smooth, } \\
\text { wavy }\end{array}$ & Intermediatt & Salmon & White \\
\hline Banana & Elongate & Prostrate & Superficial & Gray & Wavy & Intermediatt & Salmon & Brown \\
\hline $\begin{array}{l}\text { Flattened with } \\
\text { orange flesh }\end{array}$ & Flattened & $\begin{array}{l}\text { Prostrate, } \\
\text { semibushy }\end{array}$ & $\begin{array}{l}\text { From absent to } \\
\text { deep }\end{array}$ & $\begin{array}{l}\text { Gray, black, } \\
\text { white, green }\end{array}$ & $\begin{array}{l}\text { Smooth, wavy, } \\
\text { warty, wrinkled }\end{array}$ & $\begin{array}{c}\text { From soft } \\
\text { to hard }\end{array}$ & Orange & $\begin{array}{l}\text { White, brown, } \\
\text { orange }\end{array}$ \\
\hline $\begin{array}{l}\text { Flattened to globular } \\
\text { with light flesh } \\
\end{array}$ & $\begin{array}{l}\text { Flattened, } \\
\text { globular }\end{array}$ & $\begin{array}{l}\text { Prostrate, } \\
\text { semibushy }\end{array}$ & $\begin{array}{l}\text { From absent to } \\
\text { intermediate }\end{array}$ & $\begin{array}{l}\text { Gray, black, } \\
\text { green, cream }\end{array}$ & $\begin{array}{l}\text { Smooth, } \\
\text { wavy }\end{array}$ & $\begin{array}{c}\text { Soft, } \\
\text { intermediat } \epsilon \text { S }\end{array}$ & $\begin{array}{l}\text { Salmon, white, } \\
\text { yellow }\end{array}$ & $\begin{array}{l}\text { White, brown, } \\
\text { orange }\end{array}$ \\
\hline $\begin{array}{l}\text { Globular with } \\
\text { orange flesh }\end{array}$ & Globular & Prostrate & $\begin{array}{l}\text { From superficial } \\
\text { to deep }\end{array}$ & Gray, orange & $\begin{array}{l}\text { Smooth, } \\
\text { wavy }\end{array}$ & $\begin{array}{c}\text { Soft, } \\
\text { intermediate }\end{array}$ & Orange & White, brown \\
\hline Cylindrical to oval & $\begin{array}{c}\text { Cylindrical, } \\
\text { oval }\end{array}$ & Prostrate & $\begin{array}{l}\text { From } \\
\text { superficial to } \\
\text { deep }\end{array}$ & Gray, green & $\begin{array}{l}\text { Smooth, } \\
\text { wavy }\end{array}$ & $\begin{array}{l}\text { From soft } \\
\text { to hard }\end{array}$ & $\begin{array}{l}\text { White, salmon, } \\
\text { orange }\end{array}$ & $\begin{array}{l}\text { White, brown, } \\
\text { orange }\end{array}$ \\
\hline Heart-shaped & $\begin{array}{l}\text { Heart- } \\
\text { shaped }\end{array}$ & $\begin{array}{l}\text { Prostrate, } \\
\text { semibushy }\end{array}$ & Intermediate & Gray, black & Wavy & $\begin{array}{c}\text { From soft } \\
\text { to hard }\end{array}$ & $\begin{array}{l}\text { Yellow, } \\
\text { orange }\end{array}$ & Brown \\
\hline $\begin{array}{l}\text { Similar to } \\
\text { Hubbard }\end{array}$ & Elliptical & $\begin{array}{l}\text { Prostrate, } \\
\text { semibushy }\end{array}$ & $\begin{array}{l}\text { Superficial, } \\
\text { intermediate }\end{array}$ & Gray, green & Wavy & Soft & $\begin{array}{l}\text { Salmon, } \\
\text { orange }\end{array}$ & $\begin{array}{l}\text { White, } \\
\text { brown }\end{array}$ \\
\hline AN71 & Oval & Prostrate & Intermediate & Gray & Wrinkled & Soft & Orange & White \\
\hline CM34 & Flattened & Prostrate & Superficial & Gray, red & Wavy & Soft & Orange & White \\
\hline PER459 & Elliptical & Prostrate & Superficial & Green & Smooth & Intermediate & Yellow & Brown \\
\hline ARG6 & Globular & Bushy & Superficial & Black & Smooth & Soft & Orange & White \\
\hline AFR19 & Flattened & Prostrate & Absent & Gray, red & Smooth & Soft & Salmon & White \\
\hline OCE1 & $\begin{array}{l}\text { Flattened } \\
\text { turbaniform }\end{array}$ & Prostrate & Superficial & Gray & Smooth & Soft & Orange & $\begin{array}{l}\text { White and } \\
\text { brown }\end{array}$ \\
\hline
\end{tabular}

\begin{tabular}{|c|c|c|c|c|c|c|c|c|c|c|c|}
\hline $\begin{array}{l}\text { Morphological } \\
\text { group }\end{array}$ & $\begin{array}{c}\text { Fruit } \\
\text { weight } \\
\text { (kg) }\end{array}$ & $\begin{array}{l}\text { Fruit } \\
\text { length } \\
\text { (cm) }\end{array}$ & $\begin{array}{l}\text { Fruit } \\
\text { width } \\
\text { (cm) }\end{array}$ & $\begin{array}{l}\text { Length } \\
\text { width }^{-1}\end{array}$ & $\begin{array}{l}\begin{array}{l}\text { Skin } \\
\text { thickness } \\
\text { (mm) }\end{array} \\
\end{array}$ & $\begin{array}{c}\text { Flesh } \\
\text { thickness } \\
(\mathrm{cm})\end{array}$ & $\begin{array}{l}\mathrm{FF} \mathrm{L}^{-1} \\
\mathbf{W}^{-1 z}\end{array}$ & $\begin{array}{r}\text { Seed } \\
\text { length } \\
(\mathrm{cm})\end{array}$ & $\begin{array}{l}\text { Seed } \\
\text { width } \\
\text { (cm) }\end{array}$ & $\begin{array}{c}\text { Seed } \\
\text { thickness } \\
(\mathbf{m m})\end{array}$ & $\begin{array}{l}100 \text { seeds } \\
\text { weight }(\mathrm{g})\end{array}$ \\
\hline Turban & $1.5 \pm 0.4$ & $12.2 \pm 1.4$ & $15.6 \pm 2.5$ & $8 \pm 0.1$ & $2.1 \pm 0.3$ & $2.9 \pm 0.2$ & 0.2 & $1.7 \pm 0.1$ & $1.2 \pm 0.1$ & $4.0 \pm 0.4$ & -3.7 \\
\hline Banana & $18.7+2.3$ & \pm 5.6 & $32.5 \pm 3.5$ & \pm 0.1 & $1.5 \pm 0.4$ & $5.5 \pm 0.9$ & $0.1 \pm 0.0$ & $2.5 \pm 0.1$ & $1.5 \pm 0.1$ & $7.6 \pm 0.3$ & 59.08 \\
\hline $\begin{array}{l}\text { Flattened with } \\
\text { orange flesh }\end{array}$ & $5.6 \pm 3.4$ & $5.7 \pm 4.1$ & $7.0 \pm 7.0$ & $6 \pm 0.1$ & $3.2 \pm 2.0$ & $4.3 \pm 1.1$ & $0.2 \pm 0.0$ & $2.1 \pm 0.2$ & $1.2+0.2$ & $4.9 \pm 1.3$ & 34.7 \\
\hline $\begin{array}{l}\text { Flattened to globular } \\
\text { with light flesh }\end{array}$ & $10.6 \pm 4.3$ & $28.1 \pm 8.0$ & $32.6 \pm 5.5$ & $0.9 \pm 0.2$ & $2.4 \pm 1.2$ & $4.2 \pm 0.8$ & $0.2 \pm 0.0$ & $2.2 \pm 0.2$ & $1.4 \pm 0.1$ & $5.1 \pm 0.8$ & $37.2 \pm 7.8$ \\
\hline $\begin{array}{l}\text { Globular with } \\
\text { orange flesh }\end{array}$ & $7.4 \pm 4.5$ & $21.8 \pm 6.1$ & $25.4 \pm 6.2$ & $0.9 \pm 0.1$ & $2.4 \pm 1.7$ & $4.0 \pm 1.1$ & $0.2 \pm 0.0$ & $2.2 \pm 0.2$ & $1.2 \pm 0.1$ & $4.6 \pm 0.8$ & 10.0 \\
\hline $\begin{array}{l}\text { Cylindrical to } \\
\text { oval }\end{array}$ & $7.1 \pm 4.4$ & $30.6 \pm 6.2$ & $3.9+5.4$ & $.3 \pm 0.4$ & $1.4 \pm 0.4$ & $3.4 \pm 1.0$ & $0.1 \pm 0.0$ & $2.2 \pm 0.3$ & $1.2 \pm 0.2$ & $4.6 \pm 1.1$ & $31.3 \pm 13.1$ \\
\hline Heart-shaped & $8.6 \pm 4.8$ & $27.7 \pm 4.4$ & $26.0 \pm 6.7$ & $1.1 \pm 0.1$ & $1.0 \pm 0.6$ & $3.3 \pm 0.7$ & .0 & $2.2 \pm 0.2$ & $1.2 \pm 0.1$ & $5.5 \pm 0.3$ & $=16.4$ \\
\hline $\begin{array}{l}\text { Similar to } \\
\text { Hubbard }\end{array}$ & $5.2 \pm 0.1$ & .5 & 2 & .1 & 0.4 & $3.0 \pm 0.4$ & .0 & $4 \pm 0.5$ & \pm 0.2 & 0.7 & \pm 17.1 \\
\hline AN71 & $11.5 \pm 1.5$ & $36.8=$ & 3 & $.2 \pm 0.1$ & .4 & $4.0=$ & $0.1 \pm 0.0$ & $2.1 \pm 0.1$ & $1.2 \pm 0.0$ & $3.4 \pm 0.4$ & 23.23 \\
\hline $\mathrm{CM} 34$ & $2.2 \pm 0.3$ & .0 & 2 & .1 & .2 & $4.0 \pm 1.2$ & $0.3 \pm 0.0$ & $1.9 \pm 0.1$ & $1.2 \pm 0.0$ & $3.8 \pm 0.4$ & 19.46 \\
\hline PER459 & $5.2 \pm 1.1$ & $26.3 \pm 3.1$ & $19.1 \pm 1.6$ & $1.4 \pm 0.1$ & $0.5 \pm 0.1$ & $1.8 \pm 0.9$ & $0.1 \pm 0.0$ & $2.3 \pm 0.2$ & $1.5 \pm 0.1$ & $6.2 \pm 0.7$ & 48.08 \\
\hline ARG6 & $0.5 \pm 0.2$ & $8.2 \pm 2.4$ & $13.6 \pm 2.4$ & $0.6 \pm 0.2$ & $1.7 \pm 0.6$ & $1.6 \pm 0.6$ & $0.2 \pm 0.1$ & $1.6 \pm 0.0$ & $0.8 \pm 0.1$ & $2.8 \pm 0.0$ & 14.15 \\
\hline AFR19 & $11 \pm 0.8$ & $16.3 \pm 2.6$ & $43.5 \pm 5.1$ & $0.4 \pm 0.1$ & $1.5 \pm$ & $4.6 \pm 0.8$ & $0.2 \pm 0.0$ & $1.7 \pm 0.1$ & $1.1 \pm 0.1$ & $3.0 \pm 0.1$ & 20.62 \\
\hline OCE1 & $2.5 \pm 1.0$ & $11.4 \pm 1.3$ & $21.3 \pm 4.6$ & $0.6 \pm 0.1$ & $1.4 \pm 0.5$ & $3.6 \pm 1.2$ & $0.2 \pm 0.1$ & $1.9 \pm 0.1$ & $1.1 \pm 0.1$ & $3.2 \pm 0.2$ & 18.95 \\
\hline
\end{tabular}

zFlesh thickness 2 fruit length to 1 fruit width to 1 ratio (an estimate of the proportion of flesh in the fruit). The first number of the quantitative data is the mean value of all the characterized fruit of a given morphotype and the second number is the standard deviation. 


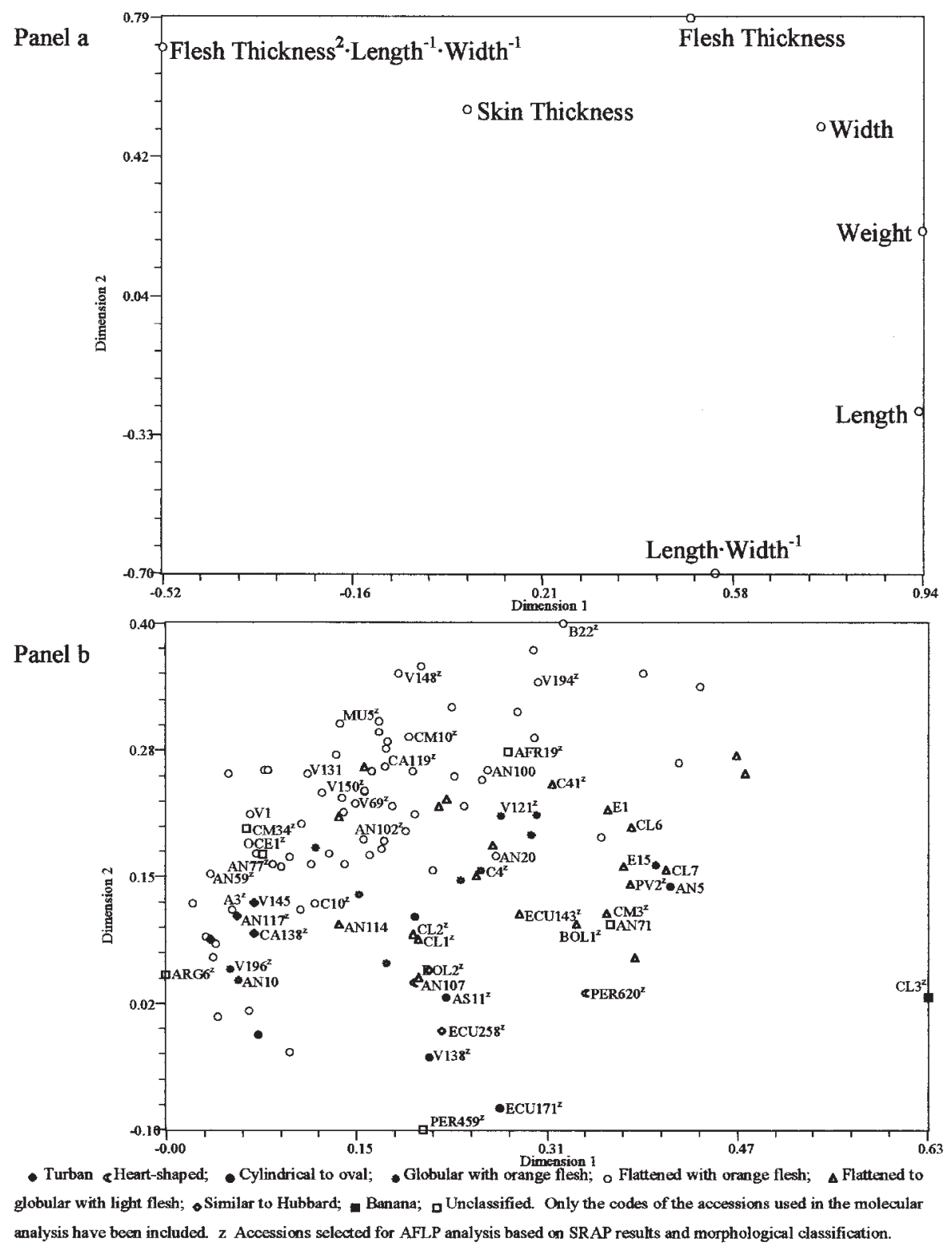

Li (1979) similarity coefficient. Two types of analyses were applied: 1) unweighted pairgroup method, arithmetic mean (UPGMA), a SAHN clustering technique (Sneath and Sokal, 1973), which compresses the patterns of variation into two-dimension branch diagrams (dendrograms); and 2) principal coordinate analysis ( $\mathrm{PCoA})$, an ordination method analogue of PCA applicable to discrete variation data (Gower, 1966). Cophenetic matrices constructed with cophenetic values computed for each dendrogram were compared with the original distance matrices using the Mantel matrix-correspondence test (Mantel, 1967). The reliability and robustness of the dendrograms were tested by bootstrap analysis with 1000 replications to assess branch support using PHYLIP software (Felsenstein, 1994). One accession of Cucurbita moschata Duch. was used as an outgroup. The Mantel test was also employed to determine the correlation between the elements of the SRAP and AFLP distance matrices. The statistical analyses were performed using the appropriate routines of the program NTSYS-pc (Rohlf, 1998).

\section{Results}

Morphological Characterization. The accessions characterized displayed considerable diversity for most of the morphological characters evaluated (Table $3)$.

A positive correlation between the fruit size and the length, width, thickness and weight of the seeds was observed (PCA plot not shown). Consequently, the seed characters were removed from the PCA (Fig. 2a and 2b). The first principal component, which accounted for $39.7 \%$ of the total variation, grouped the accessions mainly according to the fruit

Fig. 2. Diagram showing relationships among the quantitative characters used for the characterization of 120 accessions of Cucurbita maxima based on the two first principal components of PCA (39.7\% and $29 \%$ of the total variation respectively) (a). Relationships among the 120 accessions of $C$. maxima based on PCA using the quantitative morphological data $(\mathbf{b})$. Closed diamond = turban; open crescent $=$ heart-shaped ; closed circle $=$ cylindrical to oval; closed star $=$ globular with orange flesh; open circle $=$ flattened with orange flesh; open triangle $=$ flattened to globular with light flesh; open diamond = similar to Hubbard; closed square = banana; open square = unclassified. Only the codes of the accessions used in the molecular analysis have been included. ${ }^{2}$ Accessions selected for AFLP analysis based on SRAP results and morphological classification.

2001). The AFLP fragments between 60 to 380 bp were scored in Genographer as present (1) or absent (0).

Data analysis. Principal component analysis (PCA), an ordination method which places the $\mathrm{n}$ OTUs in a space with $\mathrm{n}-1$ dimensions, $n$ being the number of accessions, was performed using the standardized morphological quantitative data. The resulting accession grouping, along with the qualitative morphological traits, allowed a tentative classification of these accessions in morphotypes.

For SRAP and AFLP molecular analysis, genetic distances (GD) among genotypes were calculated according to the Nei and weight and size and the proportion of flesh in the fruit. The second component (29\% of the total variation), grouped the accessions mainly according to the fruit shape, flesh and skin thickness and proportion of flesh in the fruit. The third component (11.6\% of the total variation), grouped the accessions mainly according to the fruit size and weight and flesh thickness (not shown).

Based on the results of PCA, on the qualitative characters evaluated in the 120 C. maxima accessions, and on previous morphological classifications (Castetter, 1925; Decker-Walters and Walters, 2000; Robinson and Decker-Walters, 1997; Whitaker and Davis, 1962), eight morphotypes were established (Fig. 3, Table 3).

1) BanANa TYPE: The typical characteristics of banana squash include large size and elongated shape, pointed at both ends, soft rind, and brown seeds (Robinson and Decker-Walters, 1997). In the collection examined, a single accession (CL3) similar to this type was found.

2) TURBAN TYPE: Represented by four accessions (AN117, CA138, V94, and V145) originating from diverse Spanish regions. This type displayed small fruit, similar to the commercial cultivar Turk's Turban, which is used as an ornamental or consumed as 


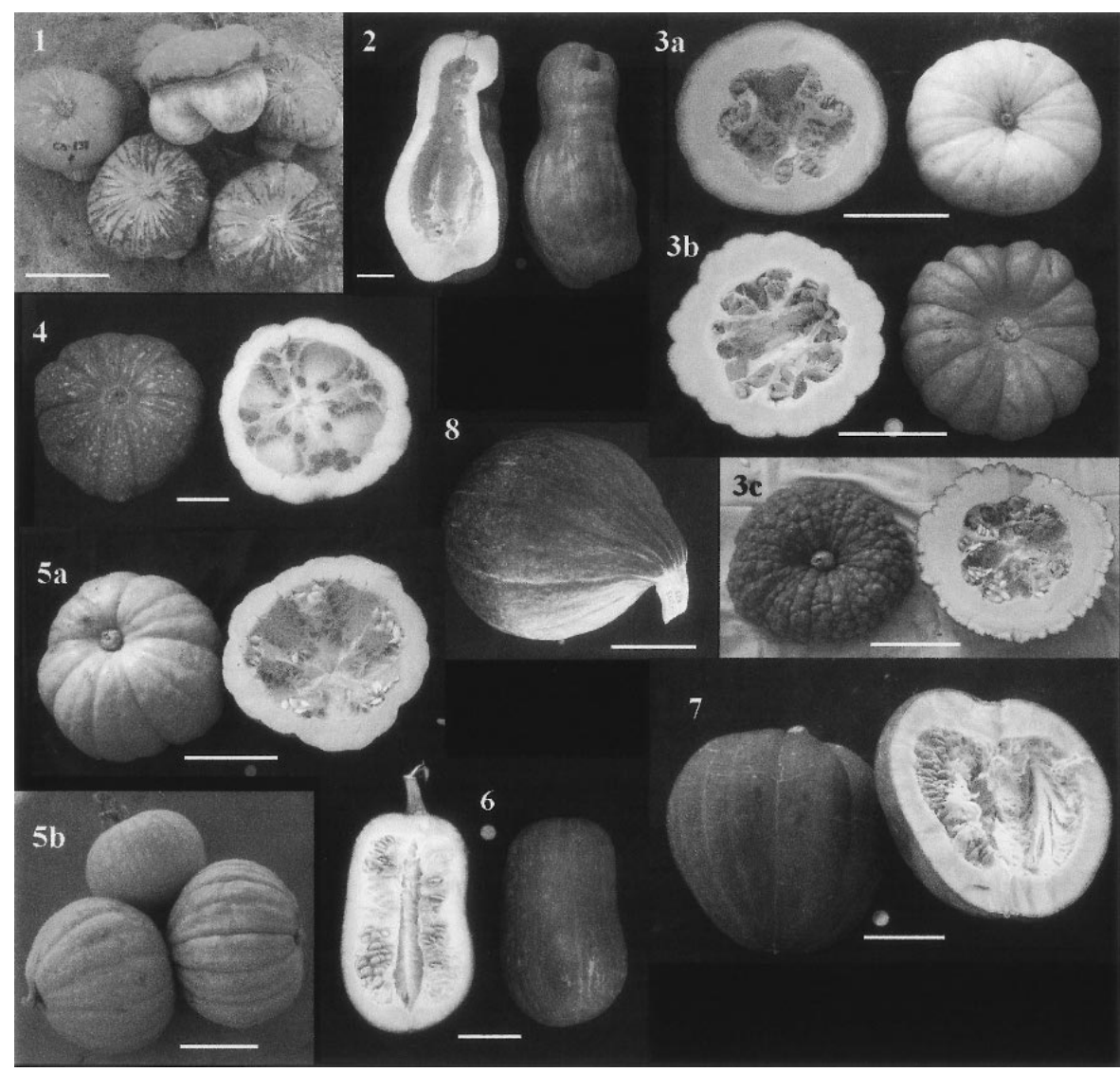

of show or display type used for competitions (Whitaker and Davis, 1962).

6) Cylindrical to oval tYPE: Six accessions from South America and Spain were of this type (BOL2,ECU171, AN5,AS11, V137, and V138). These were variable for a majority of the traits evaluated and were of different use types.

7) HearT-ShaPed TYPE: This morphotype, similar to delicious type proposed by Castetter (1925), had two representatives, the Spanish accession AN107 and the Peruvian accession PER620.

8) Hubbard type: The Spanish accession AN64 and the Ecuadorian ECU258 displayed some traits typical of this morphotype (i.e., oval fruit, tapering to curved necks at both ends).

The remaining accessions, two from Spain (AN71 and CM34), two from South America (PER459 and ARG6), one from Morocco (AFR19) and one from New Zealand (OCE1) were not characteristic of any of the categorized types, principally because of their intermediate or peculiar traits (Table $3)$. These were included as unclassified, as well as the Peruvian accession PER677, which did not produce fruit. The accession ARG6 (from Argentina) displayed the typical traits of some South American landraces, with a bushy growth habit and small fruit, which are

Fig. 3. Morphotypes of Cucurbita maxima: $1=$ turbinate, $2=$ banana, $3 \mathrm{a}=$ flattened with orange flesh, white rind, $3 \mathrm{~b}=$ flattened with orange flesh, gray and smooth rind, $3 \mathrm{c}=$ flattened with orange flesh, dark and warted rind, $4=$ flattened to globular with light flesh, $5 \mathrm{a}=$ globular with orange flesh, gray rind, $5 \mathrm{~b}=$ globular with orange flesh, orange rind, $6=$ cylindrical to oval, $7=$ heartshaped, and $8=$ similar to Hubbard. The white line $=10 \mathrm{~cm}$.

winter squash (Robinson and Decker-Walters, 1997).

3) Flattened with ORange flesh type: This type included most characterized accessions (65 of 120), collected in Southern Spain, in the regions of Andalucía, la Comunidad Valenciana, Balearic Islands, Murcia, Castilla-la-Mancha and Canary Islands. The high proportion of flesh in the fruit and its orange color determine its use for human consumption. According to the color and texture of the skin, three subtypes could be established. The majority of the accessions (41 accessions) displayed a smooth, gray skin. Furthermore, 21 accessions, mostly collected in the region of Murcia, displayed a warty skin which was variable in color, and three accessions (B10, B11, and B22), collected in the Balearic Islands, showed a bright, white skin.

4) FlatTENEd to globular With Light FLESh TyPe: Twentytwo accessions with light flesh, mainly employed for cattle consumption, were found. These accessions displayed great variability in fruit size, weight, and color and included almost all accessions originating from Extremadura and Northern Spain, and two accessions from South America.

5) GLOBULAR WITH ORANGE FLESH TYPE: Accessions belonging to this type were infrequent in this collection $(9.2 \%)$ and were heterogeneous in fruit size and weight, even though all were used for human consumption. Nine accessions had gray skin, while two accessions possessed orange skin. Fruit of one orange acession was relatively large, which is typical consumed when immature as summer squash (Nee, 1990).

The accessions of banana and turban typeswere clearly located at the opposite ends of the first principal component axis of PCA,

Fig. 4. Diagram showing relationships among 50 accessions of Cucurbita maxima based on the two first principal coordinates of PCoA $(12.7 \%$ and $10.9 \%$ of the total variation respectively) of SRAP data. Closed diamond = turban; open crescent $=$ heart-shaped; closed circle $=$ cylindrical to oval; closed star $=$ globular with orange flesh; open circle $=$ flattened with orange flesh; open triangle $=$ flattened to globular with light flesh; open diamond $=$ similar to Hubbard; closed square $=$ banana; open square $=$ unclassified. Type of use: $\mathrm{O}=$ ornamental, $\mathrm{HC}=$ human consumption, $\mathrm{CC}=$ cattle consumption. ${ }^{\mathrm{Z} A c c e s s i o n s}$ used for AFLP analysis.

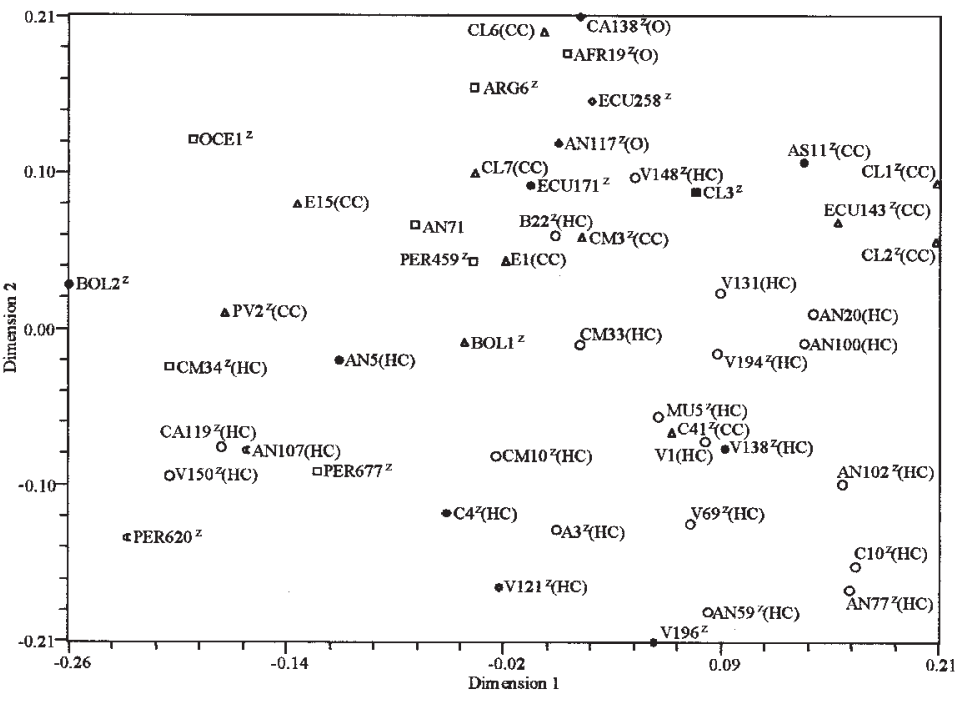

- Turban eHeart-shaped; -Cylindrical to oval; Globular with orange flesh; o Flattened with orange flessi; $\Delta$ Flattened to globular with light flesh; . Similar to Hubbard; a Banana; aUnclassified; z Accessions used for AFLP analysis. Type of use: O: Ornamental, HC: Human consumption, $\mathrm{CC}$ : Caule consumption. 
Table 4. Number of total and polymorphic fragments using SRAP and AFLP markers.

\begin{tabular}{|c|c|c|c|c|c|c|c|}
\hline \multirow{2}{*}{$\begin{array}{l}\text { SRAP } \\
\text { primer } \\
\text { combination }\end{array}$} & \multicolumn{3}{|c|}{$\begin{array}{l}\text { Variability within } \\
\text { Cucurbita maxima } \\
\text { using SRAP }\end{array}$} & \multirow{2}{*}{$\begin{array}{l}\text { AFLP } \\
\text { primer } \\
\text { combination }\end{array}$} & \multicolumn{3}{|c|}{$\begin{array}{l}\text { Variability within } \\
\text { Cucurbita maxima } \\
\text { using AFLP }\end{array}$} \\
\hline & $\mathrm{Nz}^{\mathrm{z}}$ & $\mathrm{n}^{\mathrm{y}}$ & $\mathrm{p}^{\mathrm{x}}$ & & $\mathrm{Nz}$ & $\mathrm{n}^{\mathrm{y}}$ & $\mathrm{p}^{\mathrm{x}}$ \\
\hline ME-8 $\times$ EM-3 & 12 & 3 & 25 & EcoRI-AAC x Mse-CC & 54 & 34 & 63.0 \\
\hline ME-7 x EM-6 & 6 & 1 & 16.7 & EcoRI-ACA x Mse-CG & 45 & 34 & 75.6 \\
\hline ME-2 x EM-6 & 12 & 6 & 50 & EcoRI-ACA x Mse-CT & 47 & 26 & 55.3 \\
\hline ME-7 x EM-1 & 8 & 7 & 87.5 & Total & 262 & 166 & --- \\
\hline ME-6 x EM-6 & 6 & 6 & 100 & Average & 43.7 & 27.7 & 63.4 \\
\hline ME-6 x EM-5 & 9 & 7 & 77.8 & & & & \\
\hline ME-7 x EM-5 & 8 & 7 & 87.5 & & & & \\
\hline Total & 88 & 50 & --- & & & & \\
\hline
\end{tabular}

zTotal number of bands.

yNumber of polymorphic bands, $\mathrm{x}$ : Percentage of polymorphism.

which is mostly an indicator of overall fruit size (Fig 2b). The remainder accessions, with a variable fruit size, were distributed along the first principal component axis. Based on the second component, a distribution of morphotypes mainly according to fruit shape was observed. The flattened with orange flesh accessions were grouped in the upper zone of the PCA diagram whereas the flattened to globular with light flesh accessions grouped in the central portion.

MOLECULAR CHARACTERIZATION: SRAP ANALYSIS. The analysis of 50 C. maxima accessions using 10 SRAP primer combinations identified 88 reproducible fragments (Tables 2 and 4). Among these fragments, 50 were polymorphic (56.8\%), ranging in size from $110 \mathrm{bp}$ to $950 \mathrm{bp}$. Between five and 15 fragments were amplified per primer combination, with an average of 8.8 bands observed. The number of polymorphic fragments for each primer combination varied from one to seven, with an average of five observed.

The range of dissimilarity using SRAP markers varied between 0.04 (between CL1 and CL2, these having the same passport data and belonging to the flattened to globular with light flesh morphological type) and 0.2 (between BOL2, from Bolivia, with orange flesh and belonging to the cylindrical to oval morphological type and CL2, from Spain). Some fragments were uniquely amplified in single accessions (ARG6, AFR19, V1, and AN77), while in three different cases, (E1, ECU258, and CL2), there was a unique absence of a fragment.

A cluster analysis was performed and a cophenetic coefficient of 0.94 , indicating a very good fit of the cophenetic matrix to the original distance matrix, was obtained. Few subclusters showed high bootstrap values (figure not shown). The two ornamental accessions of the turban type (AN117 and CA138) clustered together, in spite of their differing geographical origins (bootstrap $=$ 56). Four pairs of accessions originating from different Spanish regions, with similar morphological traits, also clustered together (CM10 and A3, C10 and AN59, PV2 and BOL1, and V194 and MU5; bootstrap = 82, 67, 67, and 59 , respectively).

A graphic representation of the accession distribution for SRAP data based on PCoA is shown in Fig. 4. Based on the first coordinate, which accounted for $12.7 \%$ of the total variation, an accession grouping similar to that of the morphological traits or the passport data was not detected. However, based on the second coordinate, which accounted for $10.9 \%$ of the total variation, a certain accession distribution was observed which was concordant with the established morphological types. From top to bottom

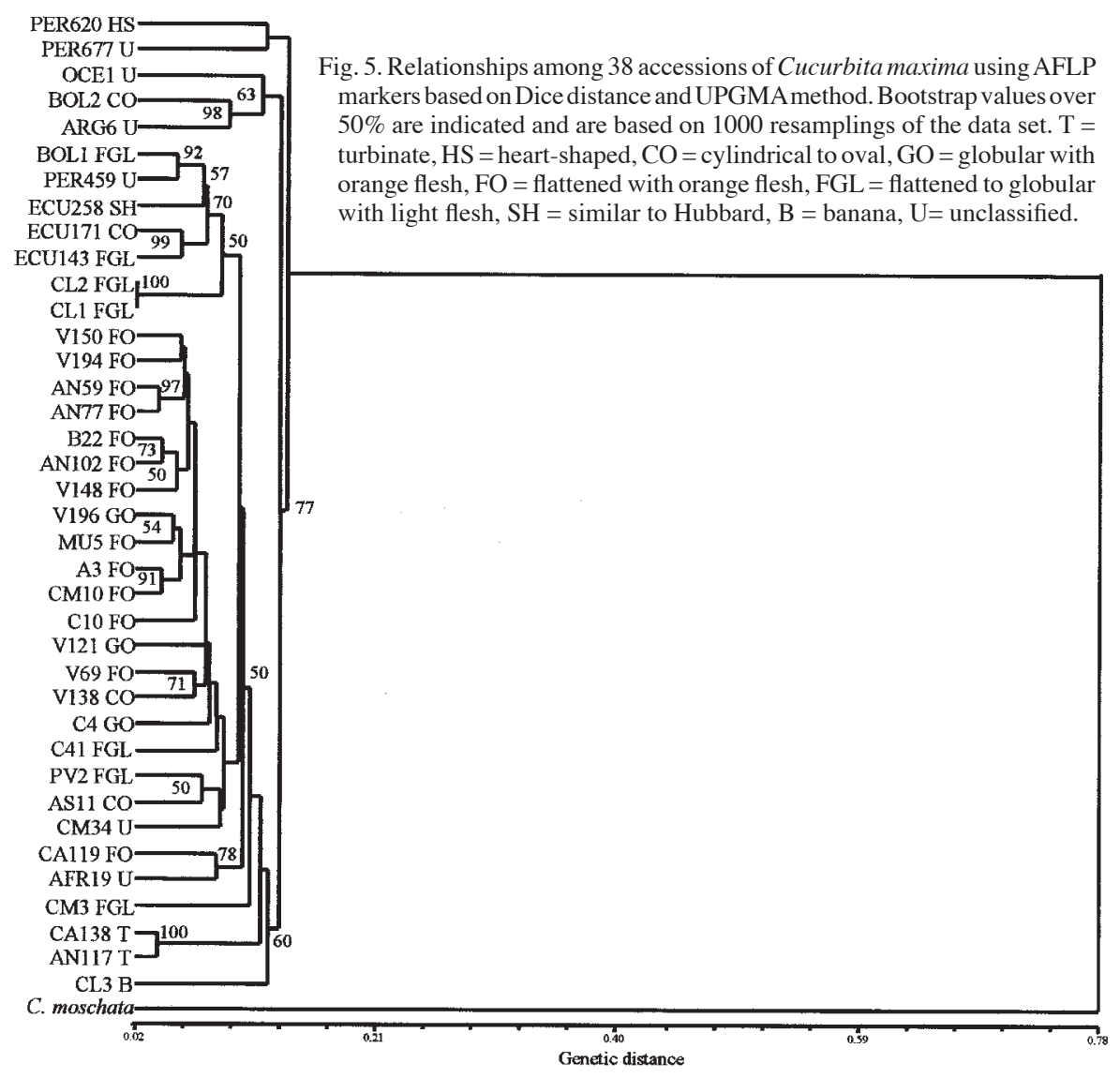




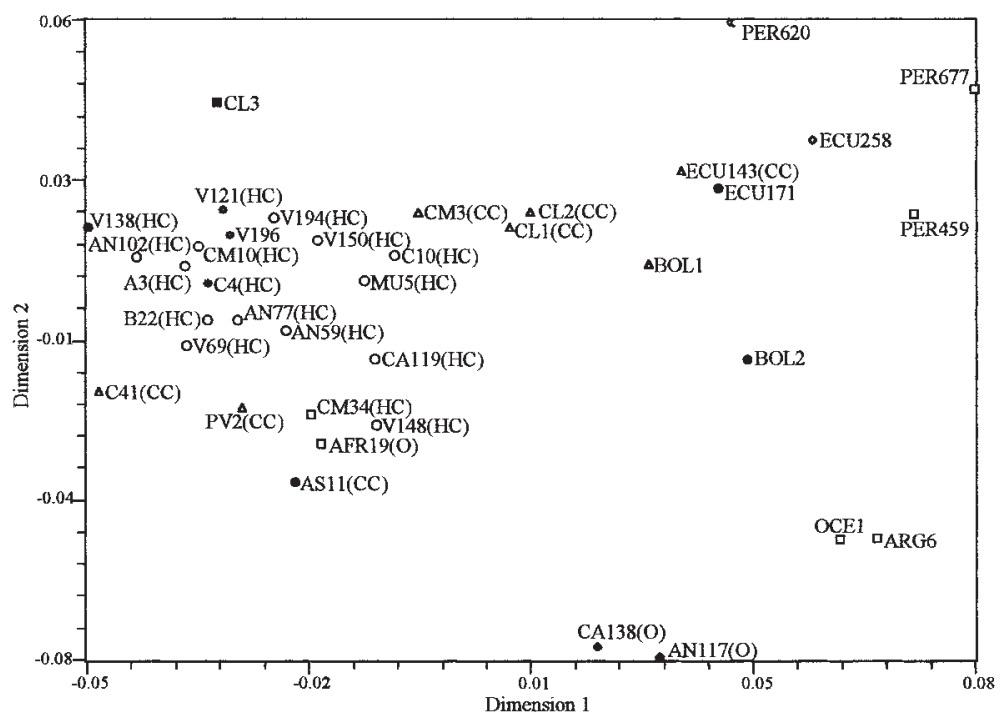

- Turban sieart-shaped; - Cylindrical to oval; - Globular with orange flesh; o Flattened with orange flesh; $\Delta$ Flattened to globular with light flesh; - Similar to Hubbard; $₫$ Banana; $\quad$ U Unclassified. Type of use: O: Ornamental, HC: Human consumption, CC: Cxttle consumption.

Fig. 6. Diagram showing relationships among 39 accessions of Cucurbita maxima based on the two first principal coordinates of PCoA $(21 \%$ and $15.6 \%$ of the total variation respectively) of AFLP data. Closed diamond = turban; open crescent $=$ heart-shaped ; closed circle $=$ cylindrical to oval; closed star $=$ globular with orange flesh; open circle $=$ flattened with orange flesh; open triangle $=$ flattened to globular with light flesh; open diamond = similar to Hubbard; closed square = banana; open square $=$ unclassified. Type of use: $\mathrm{O}=$ ornamental, $\mathrm{HC}=$ human consumption, $\mathrm{CC}=$ cattle consumption.

the turban accessions and AFR19, the only representative of the Hubbard type (ECU258), most of the flattened to globular with light flesh, most of the flattened with orange flesh, the heart-shaped and the globular with orange flesh accessions were found (Fig. 4). This distribution also agrees with a distribution in accordance with the type of use (Table 1), with the accessions used as ornamental or for cattle consumption (with white and salmon flesh) being in the upper zone of the PCoA plot and the majority of the accessions, used for human consumption (with orange flesh), in the lower zone. On the basis of the third coordinate, which accounted for $10.1 \%$ of the total variation, a certain distribution of the accessions according to geographical origin was observed (plot not shown). All the South American accessions, except ARG6, were grouped in the upper zone of the PCoA and the Spanish accessions were uniformly distributed along this axis.

AFLP ANALYSIS. For AFLP analysis, six primer combinations were used (Tables 2 and 4). A total of 262 reproducible fragments, ranging in size from $60 \mathrm{bp}$ to $380 \mathrm{bp}$, were identified, of which $145(55.34 \%)$ were polymorphic (Table 4). Between 36 and 54 fragments were amplified per primer combination, with an average of 43.7 bands. The number of polymorphic fragments for each primer combination varied from 21 to 34, with an average of 27.7 .

The range of dissimilarity varied between 0.024 (between CL1 and CL2, as with the results obtained with SRAP) and 0.18 (between the unclassified OCE1, from New Zealand, with orange flesh, and CL3, from Spain, with white flesh and belonging to the banana type). Thirty-four fragments were uniquely amplified in single accessions. Among them, nine fragments were uniquely amplified from the accession CL3, and seven from the heart-shaped PER620. Most remaining unique fragments were amplified from
South American accessions. In 17 cases, there was a unique fragment absence.

A cluster analysis was performed and the cophenetic coefficient was 0.995 , indicating a very good fit. The cluster analysis grouped the accessions according to geographic origin:America and Spain (Fig. 5). The American accessions were grouped in three clusters, two of which were separated from the remaining accessions [PER620 and PER677 (bootstrap = 77), and ARG6, BOL2, and OCE1 (bootstrap = 63)]. The remaining American accessions (three from Ecuador, one from Bolivia and one from Peru) clustered with CL1 and CL2, from Northern Spain (bootstrap = 50). All Spanish accessions belonging to the globular with orange flesh type and almost all of the flattened with orange flesh, used for human consumption, clustered together with few accessions (10\%) of other morphological types (bootstrap $=50$ ). Five accessions from Spain and one from Morocco clustered separately from the remaining accessions. Among them, the two ornamental accessions of the turban type clustered together (bootstrap $=100)$, as well as the Canarian CA119 and the African AFR19 (bootstrap =78). Finally, the only representative of the banana type clustered separately from the remaining accessions (bootstrap $=60$ ). Using AFLPs, some pairs of accessions morphologically similar and originating from diverse Spanish regions (AN59 and AN77, A3 and CM10, B22 and AN102, and V148 and AN102) grouped with high bootstrap values $(97,91,73$, and 50 , respectively).

Figure 6 represents the distribution of the different accessions according to the two principal PCoA axes. Based on the first coordinate, which accounted for $21 \%$ of the total variation, the accessions grouped according to geographic origin. The accessions from South America, which is the center of origin of C. maxima, grouped with the accession from New Zealand (OCE1), while Spanish accessions grouped with the accession from Morocco (AFR19). The second coordinate, which accounted for $15.6 \%$ of the total variation, allowed for grouping of American accessions according to country of origin. While accessions from Peru and Ecuador grouped in the upper zone of the PCoAdiagram in relation to the second coordinate, the Bolivian accessions grouped in the central zone, and an Argentinan and a New Zealand accession grouped in the lower zone. On the basis of the third coordinate, which accounted for $10.1 \%$ of the total variation, a grouping of the accessions according to morphological or geographical criteria was not observed (plot not shown). However, the banana accession, CL3, appeared clearly separated from the remainder of the accessions. A low correlation between the GD matrices obtained with both markers was detected $(r=0.31 ; P<0.05)$.

\section{Discussion}

Morphological CHARACTERIZATION. The morphological characterization of 120 Spanish and South American landraces of $C$. maxima held at COMAV revealed a great diversity in fruit characteristics. Some of the characterized accessions could be grouped according to morphological types previously proposed by Castetter (1925), such as Hubbard, turban, banana, and show or display. Other types proposed by Castetter (1925), such as marrow (with lemon-shaped fruit), or warty (with orange, warty and hard skin) were not observed. However, the majority of the landraces in this collection could not be placed in this classification scheme, as also occurs with other landraces of C. maxima that have evolved in different countries throughout the world (Decker-Walters and 
Walters, 2000). Thus, new morphotypes were established for the Spanish local landraces based on the fruit shape and flesh color, which is related to the type of use. One of the most extended type of use for C. maxima out of South America is cattle consumption (Lira-Saade, 1995). However, in Spain, C. maxima landraces are mainly used for human consumption.

Molecular CharaCterization. A greater polymorphism level was observed with AFLP markers than with SRAP markers. These results agree with previous studies, where these two types of markers were used for analyzing the genetic diversity of a germplasm collection of C. pepo (Ferriol et al., 2003b). Furthermore, $C$. pepo showed greater polymorphism, which agrees with previous studies suggesting relatively low genetic diversity in C. maxima (Decker-Walters et al., 1990; Wilson et al., 1992).

With both SRAPs and AFLPs, some fragments were uniquely amplified in single accessions. These fragments are of great interest in optimal management of germplasm collections, as they facilitate the identification of varieties and duplicates, and verify possible pollen or seed contamination during multiplication and conservation activities.

No clear grouping of the accessions according to morphological traits was observed in molecular analyses. This result agrees with previous morphological and moleculardiversity studies in C. maxima, where the allozyme data did not support the morphological classification of accessions (Decker-Walters et al., 1990; Júnior, 1999). Nevertheless, a certain distribution of the accessions of the different morphotypes related to their type of use was observed in the PCoA diagram using SRAPs. Since SRAPs detect variability mainly in coding regions, this grouping can emerge from differences in morphological traits, such as flesh color and many other agronomic traits that determine the type of use in C. maxima. This grouping based on type of use is in agreement with a previous study, where SRAPs were used to analyze a smaller group of 19 C. maxima accessions (Ferriol et al., 2003a).

With AFLPs, the C. maxima accessions were clearly grouped according to geographical origin (America and Spain). In contrast, a previous analysis with AFLP markers in C. pepo did not separate Spanish and American accessions (Ferriol et al., 2003b). These differences could be due to the greater economic importance of $C$. pepo. The existence of a higher number of commercial cultivars in this species implies a great material exchange between the two continents (Paris, 2001).

Although only nine South American accessions were included, cluster analysis with AFLPs showed greater genetic dissimilarity among them than among Spanish accessions. The fact that five accessions from South America shared a greater similarity with Spanish accessions than with other South American accessions may suggest that only a part of the existing genetic variability of the South American squashes is represented in Spain. Furthermore, our results suggest that the Spanish C. maxima accessions did not originate from squashes coming from a single American region. In fact, early Spaniards noted that landraces of C. maxima were being grown in different parts of South America (Decker-Walters and Walters, 2000). Ever since the $16^{\text {th }}$ century, various squash morphotypes spread to Central and North America, and some of them likely arrived from different parts of South America to Spain. Other cultivars could have reached Europe later via Asia, Australia, and Africa, where local landraces evolved.

The PCoA analysis with AFLPs also showed a grouping of the American accessions according to the country of origin. In
South America, C. maxima is a minor crop grown for milleniums in traditional systems for self-consumption. Its adaptation to different agroecological sites has resulted in an enormous number of heterogeneous landraces. It is assumed that the $C$. maxima ancestor, C. maxima spp. andreana, grows in temperate areas of Argentina (Sanjur et al., 2002). The potential zone of C. maxima domestication can extend into Bolivian regions. In addition, currently available archaeological data show that $C$. maxima was grown on the Peruvian coast by $\approx 4000 \mathrm{bp}$. Therefore, the coexistence in South America of the cultivated species and the related wild species, which still grow in some regions as weeds, could also explain the differentiation of the South American accessions (Lira-Saade, 1995).

Some pairs of Spanish accessions morphologically similar and originating in diverse Spanish regions, grouped consistently (with high bootstrap values) with both molecular markers. This may suggest seed exchange among farmers from different geographic regions of Spain. The same has been reported to occur among farmers in Malawi and Zambia, where $40 \%$ of the C. moschata seeds are exchanged (Gwanama et al., 2000). This exchange among farmers could be the reason why the clustering pattern of Spanish C. maxima accessions was not concordant with origin despite the diverse geographic growing regions, in contrast with the grouping observed among the American accessions.

On the other hand, the accessions of some morphological types, such as banana and turban, which grouped separately from the remainder accessions in both morphological and molecular characterization, are of great interest in plant breeding, pointing out the importance of the plant genetic resources held at COMAV.

The low correlation between the accession groupings obtained with SRAPs and AFLPs is possibly due to the different information obtained by the two marker systems used. While the SRAPmarkers preferentially amplify ORFs, which include coding regions of the genome involved in morphological and agronomic traits, AFLP markers amplify both coding and neutral regions of the genome. Furthermore, the different markers used may cover different genome regions. Recent studies carried out with tomato have shown that AFLP markers obtained using EcoRI:MseI enzymes are not uniformly distributed over the genetic map, being mainly clustered in the centromeres (Bonnema et al., 2002). This clustering was, however, not evident for melon AFLPs (Wang et al., 1997), which as Cucurbita, belongs to Cucurbitaceae. The low correlation between AFLP and SRAP results reveals the complementarity of both marker systems for analyzing the diversity of germplasm collections in this and other species.

\section{Literature Cited}

Benham, J.J. 2001. Genographer, version 1.6.0. Montana State Univ. Bonnema G., P. van der Berg, and P. Lindhout. 2002. AFLPs mark different genomic regions compared with RFLPs: a case study in tomato. Genome 45:217-221.

Castetter, E.F. 1925. Horticultural groups of cucurbits. Proc. Amer. Soc. Hort. Sci. 22:338-340.

Decker-Walters, D.S., T.W. Walters, U. Poluszny, and P.G. Kevan. 1990. Genealogy and gene flow among annual domesticated species of Cucurbita. Can. J. Bot. 68:782-789.

Decker-Walters, D.S. and T.W. Walters. 2000. Squash, p. 335-351. In: K.F. Kiple and K.C. Ornelas (eds.). The Cambridge world history of food. Cambridge Univ. Press, U.K.

Doyle, J.J. and J.L. Doyle. 1990. Isolation of plant DNA from fresh tissue. FOCUS 12:13-15.

Esquinas-Alcázar, J.T. and P.J. Gulick. 1983. Genetic resources of Cucurbitaceae: A global report. 1st ed. Intl. Board Plant Genet. Resour., 
IBPGR Secretariat, Rome, Italy.

Felsenstein, J. 1994. Phylogeny Inference Package (PHYLIP), version 3.6. Univ. Wash., Seattle.

Ferriol, M., B. Picó, and F. Nuez. 2003a. Genetic diversity of some accessions of Cucurbita maxima from Spain using RAPD and SBAP markers. Genet. Res. Crop Evol. 50:227-238.

Ferriol, M., B. Picó, and F. Nuez. 2003b. Genetic diversity of a germplasm collection of Cucurbita pepo using SRAP and AFLP markers. Theor. Appl. Genet. 107:271-282.

Ganal,M. and V.Hemleben. 1986. Comparison of the ribosomal RNAgenes in four closely related Cucurbitaceae. Plant. Syst. Evol. 154:63-77.

Goldberg, R.B., W.P. Bemis, and A. Siegel. 1972. Nucleic acid hybridization studies within the genus Cucurbita. Genetics 72: 253-266.

Gower, J.C. 1966. Some distances properties of latent root and vector methods used in multivariate analysis. Biometrika 53:315-328.

Gwanama, C., M.T. Labuschagne, and A.M. Botha. 2000. Analysis of genetic variation in Cucurbita moschata by random amplified polymorphic DNA (RAPD) markers. Euphytica 113:19-24.

Jobst, J., K. King, and V. Hemleben. 1998. Molecular evolution of the internal transcribed spacers (Its1 and Its2) and phylogenetic relationships among species of the family Cucurbitaceae. Mol. Phylogenet. Evol. 9:204-219.

Joshi, D.C., S.K. Das, and R.K. Mukherjee. 1993. Physical properties of pumpkin seeds: J. Agr. Eng. Res. 54:219-229.

Júnior, A.T.A. 1999. Divergência genética entre acessos de moranga do banco de germoplasma de hortaliças de Universidade Federal de Viçosa. Hort. Bras. 17:3-6.

Katzir, N., Y. Danin-Poleg, G. Tzuri, Z. Karchi, U. Lavi, and P.B. Cregan. 1996. Length polymorphism and homologies of microsatellites in several Cucurbitaceae species. Theor. Appl. Genet. 93:1282-1290.

Katzir, N., Y. Tadmor, G. Tzuri, E. Leshzeshen, N. Mozes-Daube, Y. Danin-Poleg, and H.S. Paris. 2000. Further ISSR and preliminary SSR analysis of relationships among accessions of Cucurbita pepo. Proc. VII EUCARPIA Mtg. Cucurbit Genet. Breeding 510:433-439.

King, K., J. Jobst, and V. Hemleben. 1995. Differential homogeneization and amplification of two satellite DNAs in the genus Cucurbita (Cucurbitaceae). J. Mol. Evol. 41:996-1005.

Li, G. and C.F. Quiros. 2001. Sequence-related amplified polymorphism (SRAP), a new marker system based on a simple PCR reaction: its application to mapping and gene tagging in Brassica. Theor. Appl.
Genet. 103:455-461.

Lira-Saade, R. 1995. Estudios taxonómicos y ecogeográficos de las Cucurbitaceae latinoamericanas de importancia económica. 1st ed. Systematic and ecogeographic studies on crop genepools. 9. Intl. Plant Genet. Resour. Inst., Rome, Italy.

Mantel, N. 1967. The detection of disease clustering a generalized regression approach. Cancer Res. 27:209-220.

Nee, M. 1990. The domestication of Cucurbita (Cucurbitaceae). Econ. Bot. 44:56-68.

Nei, M. and W. Li. 1979. Mathematical model for studying genetic variation in terms of restriction endonucleases. Proc. Natl. Acad. Sci. USA 79:5269-5273.

Paris, H.S. 2001. History of the cultivar-groups of Cucurbita pepo. Hort. Rev. 25:71-170.

Paris, H.S., N. Yonash, V. Portnoy, N. Mozes-Daube, G. Tzuri, and N. Katzir. 2003. Assessment of genetic relationships in Cucurbita pepo (Cucurbitaceae) using DNA markers. Theor. Appl. Genet. 106: 971-978.

Robinson, R.W. and D.S. Decker-Walters. 1997. Cucurbits. Crop production science in horticulture. CAB Intl., Oxon, U.K.

Rohlf, F.J. 1998. NTSYS-pc: Numerical taxonomy and multivariate analysis system, version 2.0, user guide. Exeter Software, New York.

Sanjur, O.I., D.R. Piperno, T.C. Andres, and L. Wessel-Beaver. 2002. Phylogenetic relationships among domesticated and wild species of Cucurbita (Cucurbitaceae) inferred from a mitochondrial gene: Implications for crop plant evolution and areas of origin. Proc. Natl. Acad. Sci. USA 99:535-540.

Sneath, P.H.A. and R.R. Sokal. 1973. Numerical taxonomy. W.H. Freeman, San Francisco.

Wang, Y.H., C.E. Thomas, and R.A. Dean. 1997. Agenetic map of melon (Cucumis melo L.) based on amplified fragment length polymorphism (AFLP) markers. Theor. Appl. Genet. 95:791-798.

Weeden, N.F. and R.W. Robinson. 1990. Isozyme studies in Cucurbita, p. 51-59. In: D.M. Bates, R.W. Robinson and C. Jeffrey (eds.). Biology and utilization of the Cucurbitaceae. Cornell Univ. Press, Ithaca, N.Y.

Whitaker, T.W. and G.N. Davis. 1962. Cucurbits: Botany, cultivation, and utilization. World Crops Books-Leonard Hill (books) LTD, London; Interscience Publ., New York.

Wilson, H.D., J. Doebley, and M. Duvall. 1992. Chloroplast DNA diversity among wild and cultivated members of Cucurbita (Cucurbitaceae). Theor. Appl. Genet. 84:859-865. 